\title{
Design of decision support system for santri admission
}

\author{
Undang Syaripuddin*, Cepy Slamet, Hendri Prabowo, and Muhammad Ali Ramdhani \\ UIN Sunan Gunung Djati Bandung,Department of Informatics, Jl. A. H. Nasution No. 105, Bandung 40614, Indonesia
}

\begin{abstract}
Pesantren requires some new qualified students through selection process for deciding academic and behavioural fairness. In this context, it is reasonable to utilize an application of a Decision Support System (DSS) to accelerate the student admission mechanisms since the existing process is unable to serve as reliable and objective procedures. The aim of this study is to design a specific computerized application that can be used to capture data of some potential students and recording relevant data for pesantren. Using a structured approach for the system design method, selection-based value is analysed by a Multi Attribute Utility Theory. The study is resulting a capable DSS application to identify students who have proper criteria and build a measurable data documentation.
\end{abstract}

\section{Introduction}

As an educational institution, pesantren nowadays is getting developed, the great number of pesantren has excellent facilities and management, and become the main study destination. Meanwhile, pesantren has limited students capacity, so that pesantren need to conduct the selection of santri admission. New santri admission as an administrative process is generally performed annually (in line with the school year) through the selection process of new santri admission conducted based on the assessment of some decided criteria. This process applies at Modern Islamic Boarding School (PPM) of Al-Ihsan, in which the selection process of santri admission there is always done manually, so the decision making of new santri admission take places a long time and is not well-documented.

In order to deal with the problem, it is required to apply information system in the assessment process and the selection process of new santri admission at PPM AlIhsan Baleendah (research object). Based on the research finding, the implementation of information systems can help people do their work effectively and efficiently [1], [2]. The decision making process that is supported by information system provides speed and accuracy in overcoming problems [3-9]. This Decision Support System (DSS) is expected to help PPM Al-Ihsan in performing the effective and efficient the process of new santri admission. Furthermore, in DSS implementation, there is needed an analytical model that will assist the assessment process of new santri candidates, where the application of the Multi Attribute Utility Theory (MAUT) method is seen to be suitable to deal with problems in the selection process of santri at PPM Al-Ihsan. This article discusses DSS design that uses MAUT model new santri admission at PPM Al-Ihsan.

\section{Methodology}

DSS is generally defined as a system that provides both ability to solve problems and ability to make communication for semi-structured problem [10,11]. In particular, DSS is defined as a system that supports the work of manager or a group of managers in solving problems by providing information or proposal towards specific decisions. The decision making process consists of four phases, namely: intelligence, design, choice, and implementation

In this study, DSS design follows a structured design, with Agile Modeling (AM) flat-form, DSS design is done with an intensive communication pattern between system developer and the user of each application design phase. The DSS which is designed in this study uses MAUT as the calculation basis to recommend student acceptance decision. The selected MAUT as a model in DSS is a scheme that evaluates the utility of the criteria used in the selection process. The assessment is done by changing the criteria assessment into numerical value by scale $0-1$, with 0 representing the worst choice and 1 the best choice. This allows direct comparison of various sizes [12]. The final result is an alternative ranking sequence. The evaluation value of all alternative (santri candidate) is defined in equation (1):

$$
v(x)=\sum_{i=1}^{n} w_{i} v_{i}(x)
$$

Where: $\quad \operatorname{vi}(\mathrm{x})=$ evaluation value from object to $\mathrm{i}$

wi $=$ weight that determines the element value to $i$ toward another element.

$\mathrm{n}=$ number of elements.

The total weight is 1 (equation (2).

For each dimension, the evaluation value of vi(x) is defined as the sum of the relevant attributes.

$$
\sum_{i=1}^{n} w_{i}=1
$$

\footnotetext{
* Corresponding author: undang_if@uinsgd.ac.id
} 
The final equation to make the best result from a number of alternatives is presented in equation (3)

$$
v_{i}(x)=\sum_{i=1}^{n} w_{a i} v_{a i}(I(a))
$$

\section{Result and Discussion}

\subsection{System Design Analysis}

System analysis is a description of software system which identifies and evaluates the problems of the expected needs so that they can be used properly.

\subsubsection{Functional Need Analysis.}

Functional needs here mean that the system shows whole activities occur in the research system. Here is a description of the functional need:

a. The access of new santri admission committee (PPSB) covers.

1) PPSB can login.

2) PPSB can add, modify and delete student data, criteria, score weight, and score.

3) PPSB can perform an algorithm process using the MAUT method.

b. The access of administration affairs covers.

1) Administration affair staff can login.

2) Administration affair staff can only modify and delete santri data.

3) Administration affair staff can conduct selection process and print the admission result of new santri candidate.

\subsubsection{Non-Functional Need.}

Non-functional need analysis is done to determine the need specification of the system, need specification involves hardware and software analysis. The proposed hardware and software specifications include:

a. Software specification includes:

1) Operating System of Window 7.

2) Sublime Text 3 for script.

3) Star UML Version 5.0 to make a draft.

4) Balsamiq Mockups 3 makes interface design.

b. Hardware specification includes:

1) Processor Intel Celeron 2 Ghz 32 bit.

2) Memory 2 GB.

3) Hardisk 50 GB.

4) Mouse, Keyboard, Monitor, and Printer.

\subsection{MAUT Method Analysis}

The method analysis in implementing the system comprises some analysis of the data needs.

a. Santri Data Analysis. New santri candidates take the entrance test and get the score of test material components.

b. Score Data Analysis. The score will be input in accordance with the fixed criteria and weight. c. Critical Data Analysis. The entrance test criteria will be tested on new santri candidates.

Table 1. Calculate manually by inserting test result data.

Table 1. The exam result of santri candidate.

\begin{tabular}{|c|c|c|c|c|c|c|}
\hline No & Name & KR01 & KR02 & KR03 & KR04 & $\begin{array}{c}\text { Total } \\
\text { score }\end{array}$ \\
\hline 1 & Santri 1 & 70.00 & 30.00 & 70.00 & 70.00 & 60.00 \\
\hline 2 & Santri 2 & 30.00 & 30.00 & 30.00 & 30.00 & 30.00 \\
\hline 3 & Santri 3 & 30.00 & 30.00 & 50.00 & 30.00 & 35.00 \\
\hline 4 & Santri 4 & 50.00 & 70.00 & 70.00 & 70.00 & 65.00 \\
\hline 5 & Santri 5 & 50.00 & 50.00 & 30.00 & 70.00 & 50.00 \\
\hline & Weight & $\mathbf{3 0} \%$ & $\mathbf{2 0} \%$ & $\mathbf{2 0} \%$ & $\mathbf{2 0} \%$ & \\
\hline
\end{tabular}

Matrix normalization follows equation (4).

$$
U(x)=\frac{x-x_{i}^{-}}{x_{i}^{+}-x_{i}^{-}}
$$

Where: $x_{i}^{-}=$the worst value of $x_{i}$;

$$
x_{i}^{+}=\text {the best value of } x
$$

The result of normalization is shown in table 2

Table 2. Normalization result.

\begin{tabular}{|c|c|c|c|c|c|}
\hline No & Name & KR01 & KR02 & KR03 & KR04 \\
\hline 1 & Santri 1 & 1 & 0 & 1 & 1 \\
\hline 2 & Santri 2 & 0 & 0 & 0 & 0 \\
\hline 3 & Santri 3 & 0 & 0 & 1 & 0 \\
\hline 4 & Santri 4 & 1 & 1 & 1 & 1 \\
\hline 5 & Santri 5 & 1 & 1 & 0 & 1 \\
\hline
\end{tabular}

Furthermore, the criteria are considered for each selection, so that the wight is obtained of each alternative

\begin{tabular}{|c|c|c|c|c|c|c|}
\hline Name & KR01 & KR02 & KR03 & KR04 & $\begin{array}{l}\infty \\
\tilde{\delta}\end{array}$ & 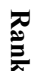 \\
\hline Santri 1 & $1 \times 30$ & $0 \times 20$ & $1 \times 20$ & $1 \times 20$ & 70 & 3 \\
\hline Santri 2 & $0 \times 30$ & $0 \times 20$ & $0 \times 20$ & $0 \times 20$ & 0 & 5 \\
\hline Santri 3 & $0 \times 30$ & $0 \times 20$ & $1 \times 20$ & $0 \times 20$ & 20 & 4 \\
\hline Santri 4 & $1 \times 30$ & $1 \times 20$ & $1 \times 20$ & $1 \times 20$ & 90 & 1 \\
\hline Santri 5 & $1 \times 30$ & $1 \times 20$ & $0 \times 20$ & $1 \times 20$ & 70 & 3 \\
\hline
\end{tabular}
with ranking order as seen in Table 3.

Table 3. Result of Ranking order.

\subsection{System Modeling}

There are two users of Context Diagram in Selection System of New Santri Candidate: New Santri Admissions Committee (PPSB) and Administration that support the system operation, as seen in Figure 1.

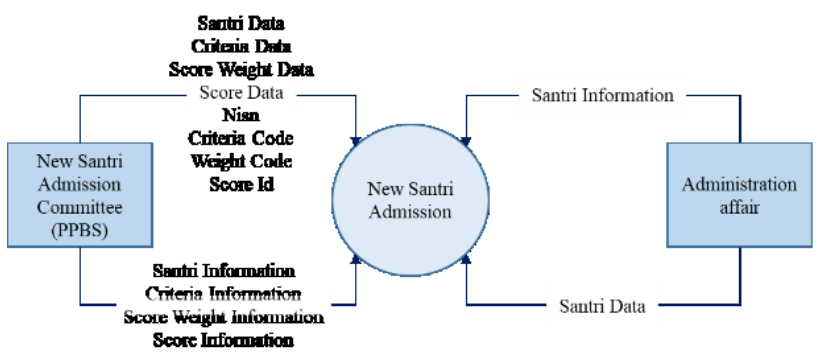

Fig. 1. Diagram Context. 


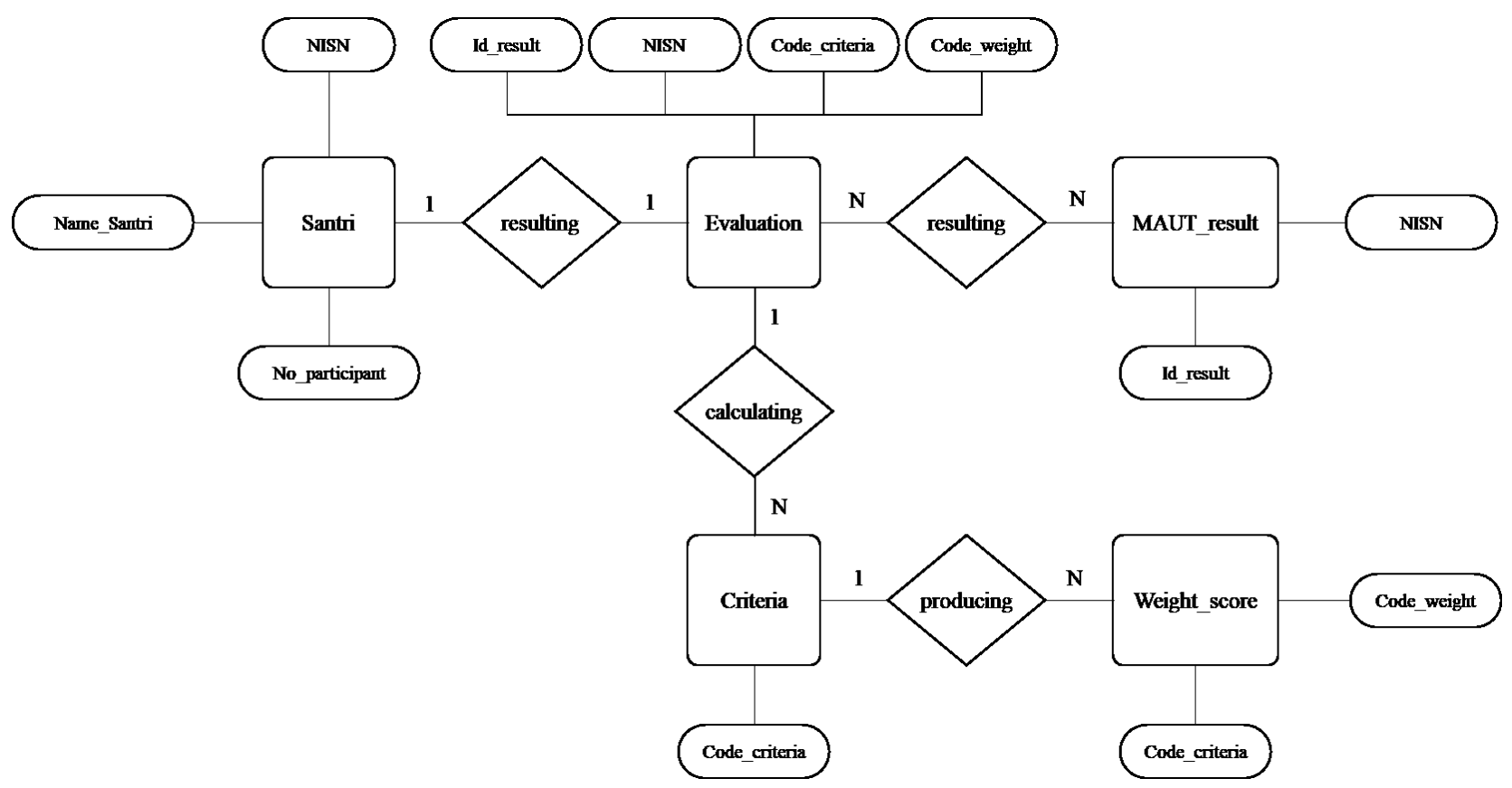

Fig. 2. ERD (Entity Relationship Diagram).

Data entry:

- Santri: (Nisn, Name_santri, No_participant, Jk, Exam, Name parent, Cost, Result, Pay, Score final, Status)

- Criteria: (Code_criteria, Name_criteria, Weight, Tot_weight)

- Weight_score: (Code_weight, Name_wight, Score_weight, Code_criteria)

- Result_maut: (Id_result, Nisn, Score)
- Assessment: (Id score, Nisn, Code criteria, Code_weight, Score, Min, Max, Score1)

In Figure 3 there is seen that PPSB can manage student data, criteria, score weight and score. The administration only manages santri data for selection process. Afterward, Entity Relationship Diagram (ERD) is designed (Figure 2). ERD is a model that describes the relationship between data in a database based on the basic objects of data that have interrelations [13].

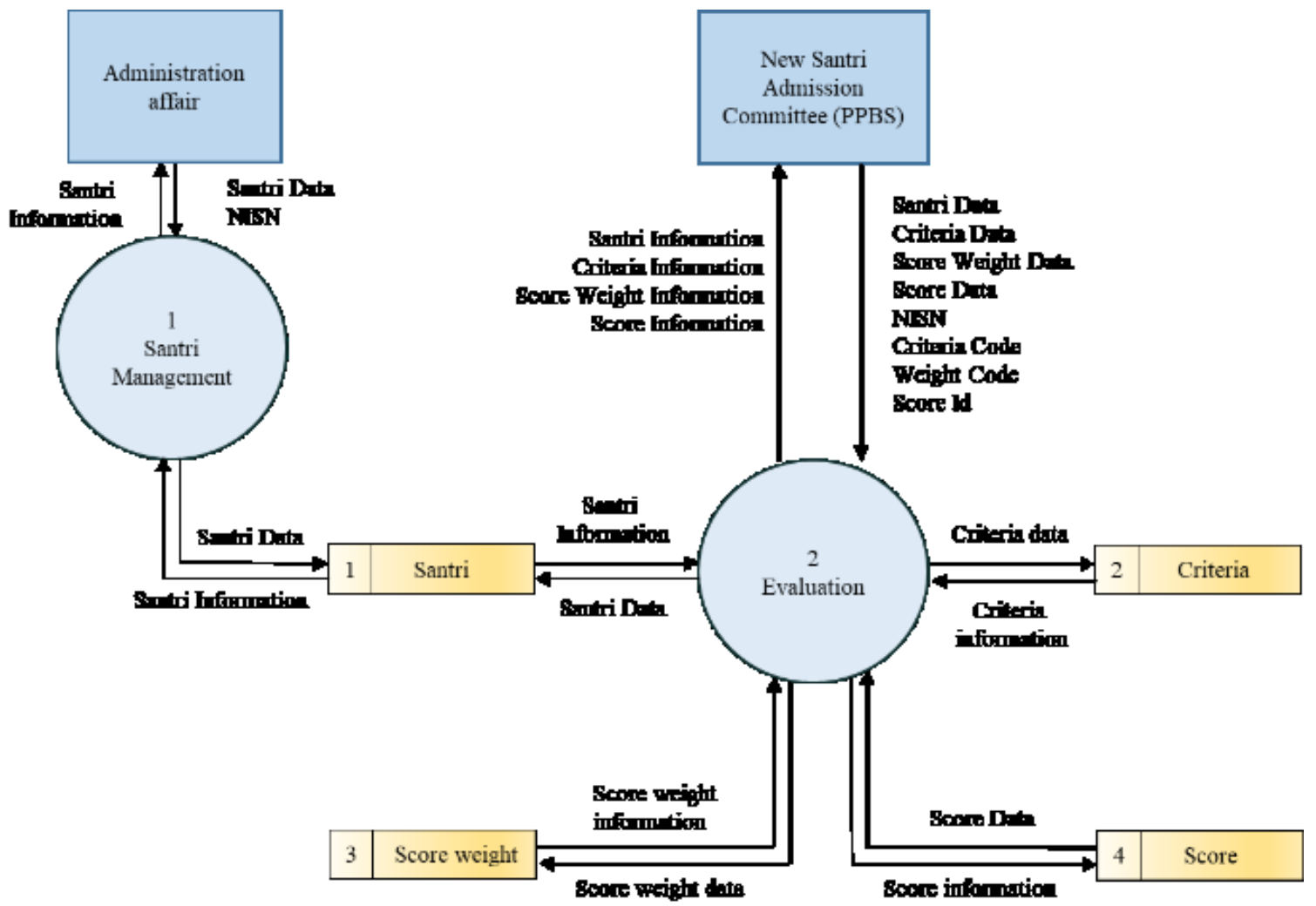

Fig. 3. Data Flow of Diagram Level 1. 


\subsection{Database Design}

The database design uses file format *.sql for its creation. Meanwhile the table of santri assessment that has been designed is presented in Tables 4 and 5.

Table 4. Structure of Assessment Table.

\begin{tabular}{|c|c|c|c|}
\hline Field & Type & Size & Description \\
\hline Id_score & Int & 5 & Primary Key \\
\hline NISN & Int & 10 & Not Null \\
\hline Code_criteria & Varchar & 10 & Not Null \\
\hline Code_weight & Int & 4 & Not Null \\
\hline Score & Decimal & 6,2 & Not Null \\
\hline Min & Int & 3 & Not Null \\
\hline Max & Int & 3 & Not Null \\
\hline Score1 & Int & 3 & Not Null \\
\hline
\end{tabular}

Table 5. Structure of maut_result table.

\begin{tabular}{|c|c|c|c|}
\hline Field & Type & Size & Description \\
\hline Id_result & Int & 5 & Primary Key \\
\hline NISN & Int & 10 & Not Null \\
\hline Score & Int & 3 & Not Null \\
\hline
\end{tabular}

\subsection{Interface Design}

Interface design is made so that the developer can customize frot-end display with client.

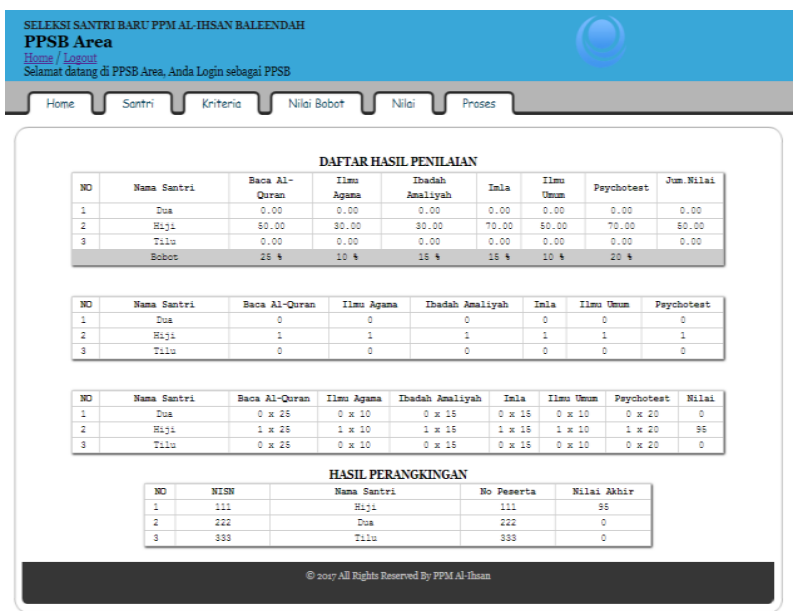

Fig. 4. Menu of PPSB-Proses.

In Figure 4. PPSB-Process is a form of PPSB to see the criteria assessment process on each student with the MAUT method. Meanwhile the final status PPSB form of santri is shown in Figure 5.

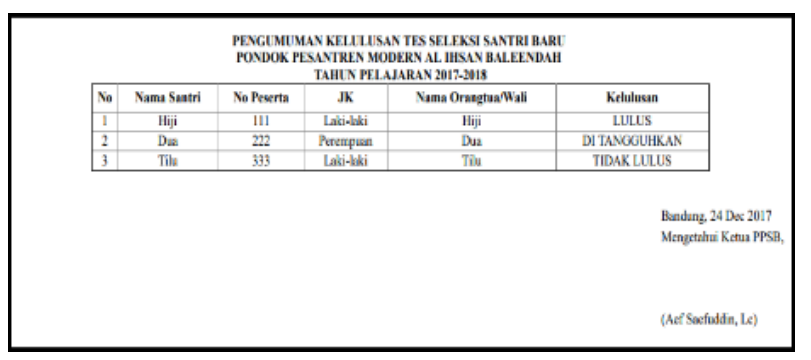

Fig. 5. Administration Menu-Print Result.

\section{Conclusion}

The built system that can select new santri candidates with optimal scores applies the implementation of MAUT method, from which the built DSS can create the information new santri passing. The performance of MAUT method in the assessment process works well, and fits the assessment of many alternatives and criteria.

\section{References}

1. A. Pamoragung, K. Suryadi, and M. A. Ramdhani, "Enhancing the implementation of e-Government in indonesia through the high-quality of virtual community and knowledge portal," in Proceedings of the European Conference on e-Government, ECEG, pp. 341-348. (2006)

2. C. Slamet, A. Rahman, A. Sutedi, W. Darmalaksana, M. A. Ramdhani, and D. S. Maylawati, "Social Media-Based Identifier for Natural Disaster," IOP Conf. Ser. Mater. Sci. Eng., vol. 288, no. 1, p. 012039, (2018)

3. Y. A. Gerhana, W. B. Zulfikar, A. H. Ramdani, and M. A. Ramdhani, "Implementation of Nearest Neighbor using HSV to Identify Skin Disease," IOP Conf. Ser. Mater. Sci. Eng., vol. 288, no. 1, p. 0121531234567890 Implementation, (2018)

4. D. S. Maylawati, W. Darmalaksana, and M. A. Ramdhani, "Systematic Design of Expert System Using Unified Modelling Language," IOP Conf. Ser. Mater. Sci. Eng., vol. 288, no. 1, p. 012047, (2018)

5. A. Rahman, C. Slamet, W. Darmalaksana, Y. A. Gerhana, and M. A. Ramdhani, "Expert System for Deciding a Solution of Mechanical Failure in a Car using Case-based Reasoning," IOP Conf. Ser. Mater. Sci. Eng., vol. 288, no. 1, p. 012011, (2018)

6. C. Slamet, R. Andrian, D. S. Maylawati, W. Darmalaksana, and M. A. Ramdhani, "Web Scraping and Naïve Bayes Classification for Job Search Engine," vol. 288, no. 1, pp. 1-7, (2018)

7. A. Taofik, N. Ismail, Y. A. Gerhana, K. Komarujaman, and M. A. Ramdhani, "Design of Smart System to Detect Ripeness of Tomato and Chili with New Approach in Data Acquisition," in IOP Conference Series: Materials Science and Engineering, vol. 288, no. 1, p. 012018. (2018)

8. W. B. Zulfikar, Jumadi, P. K. Prasetyo, and M. A. Ramdhani, "Implementation of Mamdani Fuzzy Method in Employee Promotion System," IOP Conf. Ser. Mater. Sci. Eng., vol. 288, no. 1, p. 012147, (2018)

9. D. S. Maylawati, M. A. Ramdhani, W. B. Zulfikar, I. Taufik, and W. Darmalaksana, "Expert system for predicting the early pregnancy with disorders using artificial neural network," 2017 5th Int. Conf. Cyber IT Serv. Manag. CITSM 2017, (2017)

10. Hermawan, Membangun Decision Support System. Yogyakarya: Andi, (2005)

11. K. Suryadi and M. A. Ramdhani, Sistem Pendukung Keputusan. Bandung: Remaja Rosdakarya, (2002)

12. R. Jannah, "Aplikasi Penerimaan Karyawan dengan 
Metode Multi Attribute Utility Theory," SATINSains dan Teknol. Informasi, vol. 1, no. 2, pp. 7989, (2015)

13. M. A. Ramdhani, Metodologi Penelitian untuk Riset Teknologi Informasi. Bandung: UIN Sunan Gunung Djati Bandung, (2013) 